\title{
灌溉を考慮した陸域水循環モデルの構築 DEVELOPMENT OF WATER CIRCULATION MODEL INCLUDING IRRIGATION
}

\author{
小槻峻司 1 ・田中賢治 2 - 小尻利治 ${ }^{3} \cdot$ 浜口俊雄 4 \\ Shunji KOTSUKI, Kenji TANAKA, Toshiharu KOJIRI and Toshio HAMAGUCHI \\ 1学生会員 京都大学大学院 工学研究科都市社会工学専攻（二615-8530 京都市西京区京都大学桂） \\ 2正会員 博（工） 京都大学 防災研究所 准教授（干611-0011 宇治市五ヶ庄） \\ 3正会員 博（工） 京都大学 防災研究所 教授（干611-0011 宇治市五ヶ庄） \\ 4正会員 博（農） 京都大学 防災研究所 助教（干611-0011 宇治市五ヶ庄）
}

It is well known that since agricultural water withdrawal has much affect on water circulation system, accurate analysis of river discharge or water balance are difficult with less regard for it. In this study, water circulation model composed of land surface model and distributed runoff model is proposed at $10 \mathrm{~km} \times 10 \mathrm{~km}$ resolution. In this model, irrigation water, which is estimated with land surface model, is introduced to river discharge analysis. The model is applied to the Chao Phraya River in Thailand, and reproduced seasonal water balance. Additionally, the discharge on dry season simulated with the model is improved as a result of including irrigation. Since the model, which is basically developed from global data sets, simulated seasonal change of river discharge, it can be suggested that our model has university to other river basins.

Key Words: water circulation model, irrigation, land surface process, crop calendar

\section{1.はじめに}

近年，アジアやアフリカを中心とした急激な人口増加 や経済成長に伴い，人類の水需要量は急激に増加してい る. 淡水供給システムとしての陸域水循環システムは, 非常に重要なプロセスであり1)，増加する水需要を満た す水資源管理を行う上で, 流域水循環システムの理解と 把握が求められている2). 人類の経済発展や人口増加に 伴い，農業生産活動は水循環システムに大きな影響を与 えるようになってきており，陸域水循環システムを考慮 する上で, 農業生産活動の影響を考慮する事は必要不可 久である。その様な観点から，農業生産活動の影響を考 慮した流域スケールでの陸域水循環モデルが強く求めら れている. 人間活動の中でも農業は，水循環システムに 最も影響を与える活動の一つである．現在，世界の水消 費の $80 \%$ 以上は農業用水であり ${ }^{3)}$, 人口の増加に伴い今 後も増え続けると予測されている4). 特に灌溾は, 農地 の生産性を大きく向上させ，世界では約2割の灌溉農地 から，食糧の約4割が生産されている，そこで，本研究 では，これら灌輓の効果を考慮した陸域水循環モデルの 構築を目的とする，世界では，農地の灌溉必要水量を推 定できる物理モデルは少なく，SiBUCの他には
$\mathrm{ORCHIDEE}^{5)}$ など数えるほどであり，更にそれを水循環 モデルに組み込んだ研究は十分ではない．水資源管理の 面からは，将来の気象予測值から灌湶必要水量を特定可 能なモデルを構築する事は，大きな意義があるといえる. 灌湐必要水量を求める上で, 農地における農事暦情報 の特定は必要不可欠であり, 精度のよい推定の鍵とな る. Hanasaki et al. は気温から最適な時期の農業を行うと して, 農事暦をモデル化し, 全球河川流下解析に適用し ているの。 また，谷口らは農地での積算降水量を条件に 農事暦のモデル化を行い，水田の取排水の影響を組み込 んだ水循環モデルの構築を行っている7). 本論文では, リモートセンシングデータや, 正規化植生指数NDVIを 用いた農事暦の作成手法 ${ }^{8}$ を用いる。萬らはこの手法を 全球に適用し, 土畩水分との関係を調心゙9), 更に降水量と の相関分析を行っている ${ }^{10)}$. 光学センサーによる分光反 射情報から計算される植生指標は, 植物の光合成活動そ のものを観測している事になり，モデル化された指標に 比して，作物生育の状態をより現実的に捉える事が可能 である。

本研究では，モデル内での灌溉必要水量の推定方法, それを組み込んだ陸域水循環モデルの提案を行う。また， 構築されたモデルを用いて, シミュレーションを行い, 結果を観測データと比較する. 


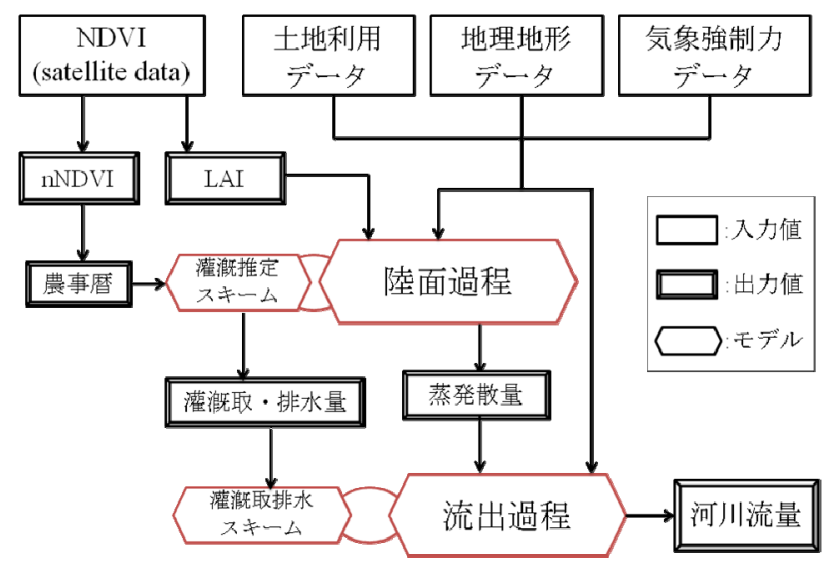

図-1 解析フロー

\section{2. モデルの構成}

構築した陸域水循環モデルは，分布型のモデルであり， 陸面過程，流出・河川流下過程の要素を持つ. 図-1に解 析のフローを示す. モデルは, 気像強制力を入力とし, 各グリッドの地表面貯水量, 河川流量, 蒸発散量, 灌激 要求水量等を出力寸る. 特に, 水資源量の把握の観点か らは, 蒸発散量の精度の高い推定が求められ, 水・熱・ 放射収支を解く陸面過程解析では，それが可能である. 以下にモデルの説明を行う.

\section{（1）陸面過程}

陸面過程は, 陸面過程モデル SiBUC ${ }^{11)}$ (Simple Biosphere including Urban Canopy)を用いて表現されてい る. SiBUCは地表面状態を緑地・都市・水体の3つの力 テゴリーに分類し，それらの混在を認めるモザイクモデ ルである. 陸面過程は, 特に鉛直方向の水の挙動の解析 に適しており, 気象強制力と地表面データより水収支・ エネルギー収支を計算し，蒸発散量や流出量等を解析す る. 陸面過程モデルの中でもSiBUCは，灌溉農地におけ る灌洦取・排水の効果を陽に扱える点を，大きな利点と して有する. SiBUCでは，農地の水深や土袞水分量を追 跡し, 農事暦における各生育段階に必要な水深や土壌水 分量を超えた場合に灌溉が行われる，といったモデル化 がなされている. 農事暦の作成を, 以下の手順で行う.

\section{(a) リモートセンシングデータの活用}

地表面の農地情報の整備に当たり, SPOTVEGETATION 10days-compositeデータ (http://free.vgt.vito.be/index.php)から, 正規化植生指数NDVIを使用する. 植 物のクロロフィルは太陽光のうち赤領域の波長を強く吸 収し, 近赤外領域の波長を強く反射寸る特徵を有する. NDVIは，この様な植物の特徽を考慮して作成された指 標である. NDVIは以下の式で与えられる.

$$
N D V I=\frac{N I R-R E D}{N I R+R E D}
$$

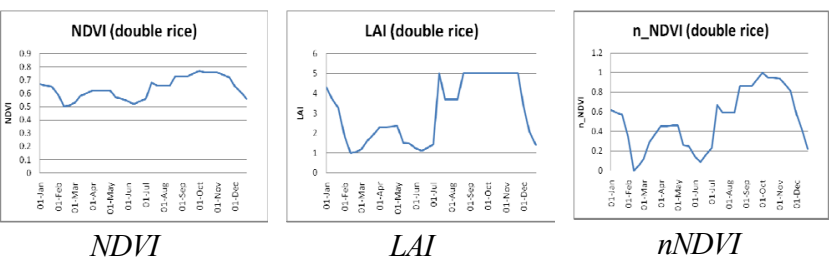

図-2 二期作地点（Lon:99.38, Lat:15.27) 年変化（2003年）

ここで，RED: 可視域における赤領域，NIR: 近赤外領 域の反射率である.

また，葉面積指数LAIをNDVIデータから，BISE法 ${ }^{12)} に$ より雲の影響を除去した上で作成する．LAIは陸面過程 解析において, 特に蒸散量を解析する上で重要なパラ メーターである.LAIは以下の式13)で計算される.

$$
\begin{gathered}
S R=\frac{1+N D V I}{1-N D V I} \\
F P A R=F P A R_{\text {min }}+ \\
\frac{\left(S R-S R_{\text {min }}\right)\left(F P A R_{\text {max }}-F P A R_{\text {min }}\right)}{\left(S R_{\text {max }}-S R_{\text {min }}\right)} \\
L A I=L A I_{\text {max }} \frac{\log (1-F P A R)}{\log \left(1-F P A R_{\text {max }}\right)}
\end{gathered}
$$

ここで，SRはSimple Ratio, FPARは光合成有効放射 吸収率であり，それらの最大・最小值は各植生に対し て与えられている.

\section{(b) 農事暦の作成}

作物の農事暦を $n N D V V$ データから作成する. $n N D V I は$ 正規化された $N D V I$ 值であり，以下の式から算出される.

$$
n N D V I(t)=\frac{N D V I(t)-\min }{\max -\min }
$$

ここで, $n N D V I(\mathrm{t})$ : 時刻 $t$ 正規化 $N D V I, N D V I(\mathrm{t})$ : 時刻 $t$ のDVI, min: 対象期間の $N D V I$ 最小值, $\max$ : 対象期間の $N D V I$ 最大值である.

$N D V I ， L A I ， n N D V I の$ 時系列はいずれも，作物の生育

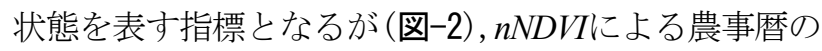
抽出が最も適当であると判断した．NDVI，LAIは，耕作 面積率に応じて值の変動範囲が大きく異なり, 耕作面積 率の低いグリッドでは，作物成長状況との対応関係が弱 くなる． NDVIを正規化した指標である $n N D V I$ は，耕作 面積率の低いグリッドにおいても, その変化を明確に示 寸ため，農事暦の抽出に適当であると言える.

\section{（2）流出過程}

流出・河川流下過程は, 分布型流出モデルHydro$\operatorname{BEAM}^{14}($ Hydrological River Basin Environment Assessment Model)を用いて表現されている. 流出・河川流下過程で は, 陸面過程解析により得られる, 蒸発散量, 灌泊要求 水量データを引き継ぎ, 流域の水平方向の水の挙動を解 析寸る. 陸面過程解析で推定された灌泊必要水量は, 実 際には河道から取水され，河道に排水される，灌激取排 水には, 灌泊必要水量の発生したグリッドから, 最も上 流にある河道グリッドから取水し，最も下流にある河 


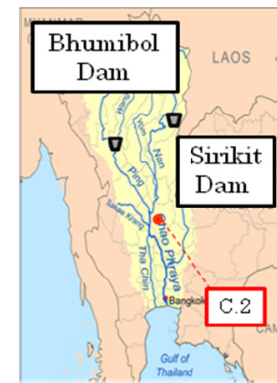

図-3 対象地域

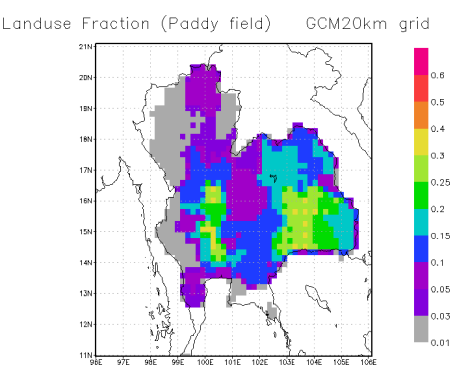

図-4 タイ水田面積率 (Agro-SEAD)

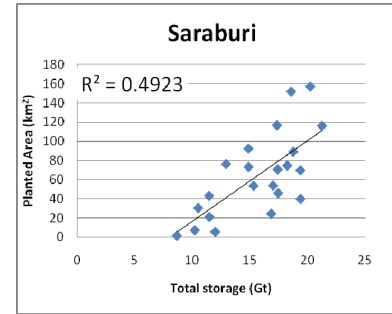

Saraburi県

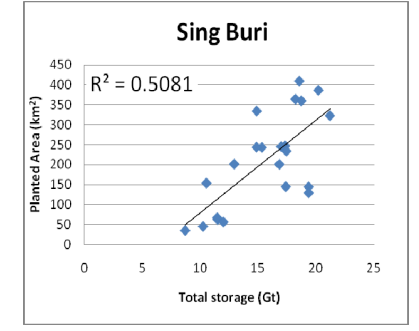

Sing Buri県
図-5 乾季初期貯水量-乾季作付面積の散布図

道グリッドに排水するとする灌溉取排水スキームを用い た. 河道からの取水に際しては，灌溉水路での漏水や蒸 発散の影響を考慮し，灌溉効率を乗じた值を用いる．灌 溉必要水量，灌激取水量は以下の式で求められる.

$$
\text { win }=\alpha \cdot I W R
$$

ここで, win: 灌激取水量, $\alpha$ : 灌溉効率, IWR:灌溉必 要水量である.

なお，本来は陸面過程の流出量を河道追跡モデルで計 算する結合が理想である。しかし，陸面過程モデルによ る基底流出量の再現精度が，特に山間部では不十分で あった。これは陸面過程モデルが地表面の水・熱収支フ ラックス推定を目的として発展してきたためである. 今 回は蒸発散量のみを引き継ぐ結合を採ったが，陸面過程 モデルの改良を行い，基底流出量の再現性度を改善して いく必要があると言える。

\section{3. モデルの適用と計算条件}

構築したモデルを，農業活動が陸域水循環に与える影 響が非常に大きい地域として，タイ・チャオプラヤ川流 域に適用した(図-3)。流域は東南アジアモンスーン域に 位置し, 雨季・乾季の差が顕著な地域である. タイは広 大な農地を有し(図-4), FAO(Food and Agriculture Organization)の統計データによると, タイ国の総水使用 量の90\%は農業に用いられている，流域上流域には，貯 水容量が $10 \mathrm{Gt}$ を超えるダムが $2 つ$ 建設されており (Bhumibol Dam, Sirikit Dam), 下流域の水循環に大きな影 響を与えている. 解析を, ダム上流域を含めた全流域を 対象に行った.ただし，ダム下流部においては，ダムが 河川流量に与える影響が非常に大きいため, EGAT (Electricity Generating Authority of Thailand)から提供され
ている2大ダムからの実放流量を境界条件として与えた.

\section{（1）気象強制力}

TMD(Thai Meteorological Department) と RID(Royal Irrigation Department)から提供されている雨量観測データ から降水量データセットを作成した．また、H08プロダ クト ${ }^{15)}$ から気温, 比湿, 下向き短波, 下向き放射のデー タセットを作成した。また，風速，気圧のデータは GSWプロダクトのJRA25の再解析データを用いた.

\section{（2）地表面パラメーター}

土壌，植生パラメーターを，Meteo-Franceにより提供 されている Ecoclimap(http://www.cnrm.meteo.fr/gmme/PROJETS/ECOCLIMAP/page_ecoclimap.htm)より切り出し 作成した。 また，土地利用情報として，USGSの提供す るGLCC version2(http://edc2.usgs.gov/glcc/)から，陸面過程 解析へは15種類, 流出解析へは5種類のカテゴリーに再 分類して作成した. USGSのデータは, FAOの統計デー タと比較すると灌溉面積を過大評価していたため, FAO による総灌溉面積と適合するように補正を行い，土地利 用情報とした。

\section{（3）地形データ}

地形情報データとして, 落水方向, 落水勾配, 斜面勾 配を，CGAIR-CSI（http://srtm.csi.cgiar.org/Index.asp）に

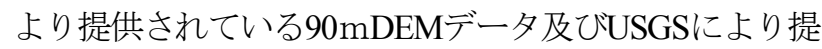
供されている $1 \mathrm{~km}$ 河道位置情報（http://eros.usgs.gov/）よ り作成した.

\section{（4）解析期間}

第一段階として，水資源量を把握する上で重要となる 蒸発散量の解析精度を検証するため, 陸面過程解析を才 フラインで実行した。解析期間は1980年から1999年まで の20年間とした．次に，陸面過程解析からの蒸発散・灌 溉取排水量を引き継いだ流出・河川流下解析を, 現地 データの十分に整った1998年を対象として行った. なお, 陸面過程解析においてSPOT-VEGETATIONのデータの 無い年度については，乾季の初期（1月1日）のBhumibol DamとSirikit Dam総貯水容量が最も近い年度のデータを 用いた。 タイにおいて，雨季はほぼすべての農地で耕作 を行うが，乾季の耕作面積決定は，乾季初期の流域の貯 水量に影響されるためである(図-5).

\section{4. 解析結果と考察}

\section{（1）年間水収支の解析結果}

図-6に1980年から 1999年までの中流域, Nakhon Sawan (以下C2) 地点集水域の年水収支の経年変化を示す. 赤グラフが観測河川流量, 緑グラフが解析総流出量, 青 


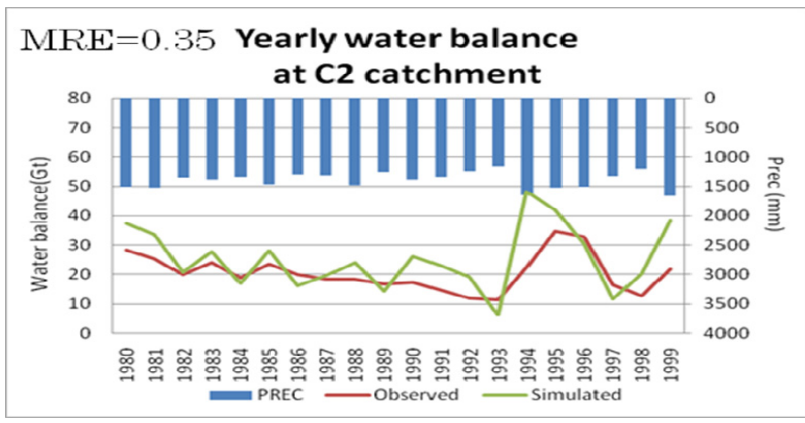

図-6 C2集水域の年水収支の経年変化

棒グラフがC2集水域平均降水量を示している，なお上 流貯水池においては, 豊水年に貯水量を増やし, 渇水年 に放流するといった操作が行われているため, 解析結果 に上流貯水池の貯水容量増加量を加えた值を示している。 年水収支は，相対誤差 $35 \%$ の精度で解析されたが，降水 量の多い年に水収支を過大評価する傾向がみられた。こ れは，雨の多い年において中流域上流で河川が汇濫し， 汇濫原において解析より多くの水が発散によって失われ るためだと考えられる. 実際にチャオプラヤ川本流域で 洪水が起こった1980年，1983年，1995年等の水収支が過 大評価である事が確認できる。なお，流域の水収支 $(W B)$ は以下の式によって計算され，集水域から対象期 間内に流出した水量を表す.

$$
\begin{gathered}
W R=\sum_{i} A_{i} \sum_{t}\left(P_{t, i}-E_{t, i}\right) \\
T W S=\sum_{i} A_{i} \cdot S W_{i} \\
I R R G=\sum_{i} A_{i} \sum_{t}\left(\alpha \cdot I W R_{t, i}-\text { Wout }_{t, i}\right)
\end{gathered}
$$

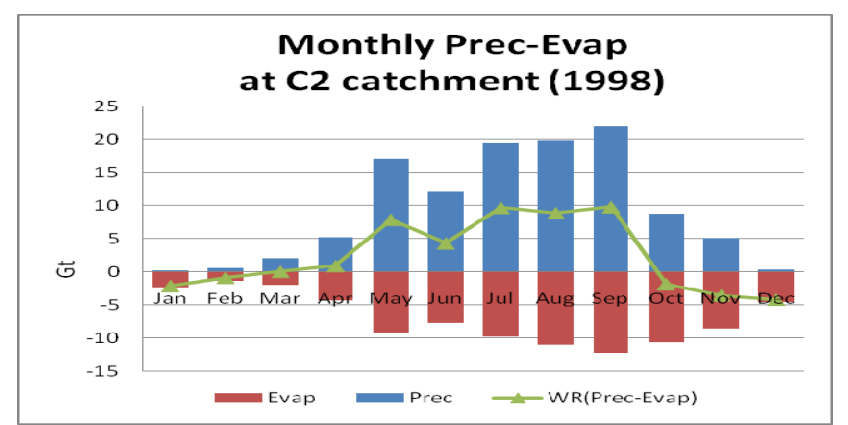

（a）降水-蒸発散変化

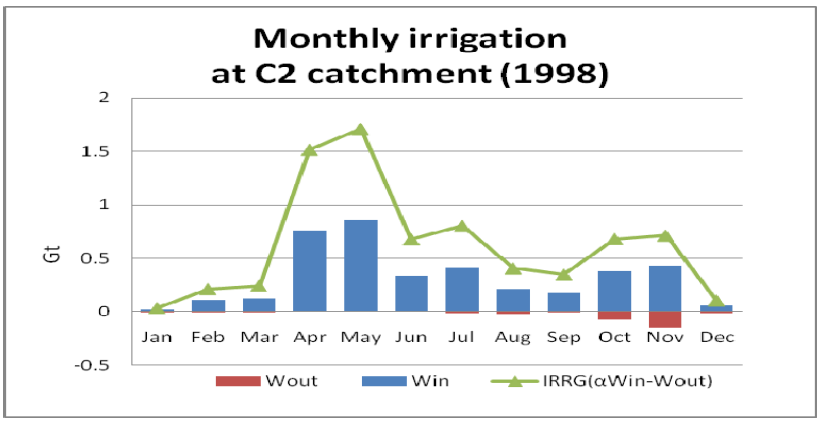

（c）灌溉取 $\cdot$ 排水量

$$
W B=W R-I R R G-\triangle T W S
$$

ここで， $i:$ グリッド， $t$ : 対象期間, $P$ : 降水量, $E$ : 蒸 発散量, $S W$ : 地表面貯水量, Wout:灌䚌排水量, $A$ : グ リッド面積, WR: 集水域水資源賦存量, TWS: 集水域地 表面貯水量, $I R R G$ : 集水域灌泊取水量である.

\section{（2）月水収支の解析結果}

陸面過程により得られた，1998年C2集水域の月水収 支解析結果を図-7に示す. 図-7(a)において, 青棒グラ フは降水量, 赤棒グラフは蒸発散量, 緑グラフはその差 (WR) を示寸. 図-7 (a) より, 雨季 (5-10月) に降雨が集 中しているのに対して, 蒸発散量が乾季にも発生し, 降 水量を上回っている事が分かる. 図-7(b)において，青 棒グラフは地表面の貯水量 $(T W S)$, 赤グラフはその変 化量 $(\Delta T W S)$ を示す. 貯水量が雨季に増加し, 乾季に減 少している状態が把握できる. 灌泊取・排水量の解析結 果を図-7 (c) に示寸. 青棒グラフが灌泊必要水量 $(\mathrm{Win})$, 赤棒グラフが灌䄽排水量 $($ Wout $)$, 緑グラフが総灌洦取水 量 $(I R R G)$ を示寸。 なお，灌激効率 $\alpha$ は 0.5 とした ${ }^{16}$. 図一 7 (d) に集水域水収支 $($ 紫グラフ, $W B$ ) と，その内訳を示寸. 図より，雨季において水収支が正になり，逆に乾季にお いて水収支が負になる傾向が分かる.これらの結果は， タイにおける雨季・乾季の季節変化を良く表現している と言える.

\section{（3）貯水池流入量の再現性}

流出・河川流下過程の出力值より，上流域ダムへの流 入量, 及び年貯水量を追跡した. なお，年初の貯水量を 初期条件としている. 両ダムの貯水容量と流入量を図-

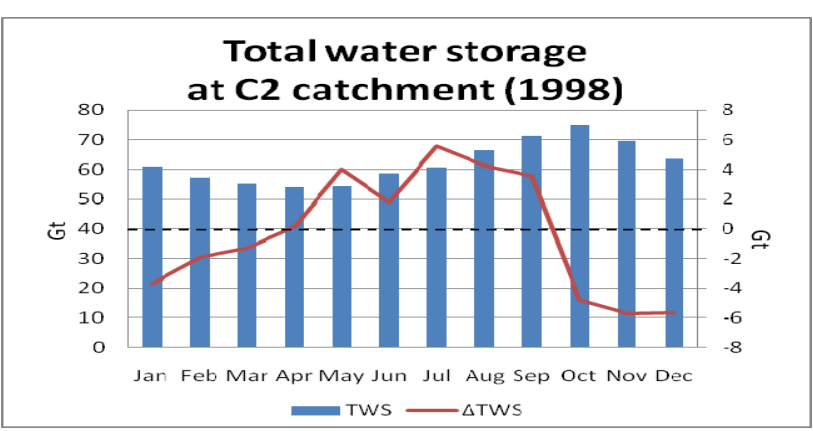

(b) 地表面貯水量

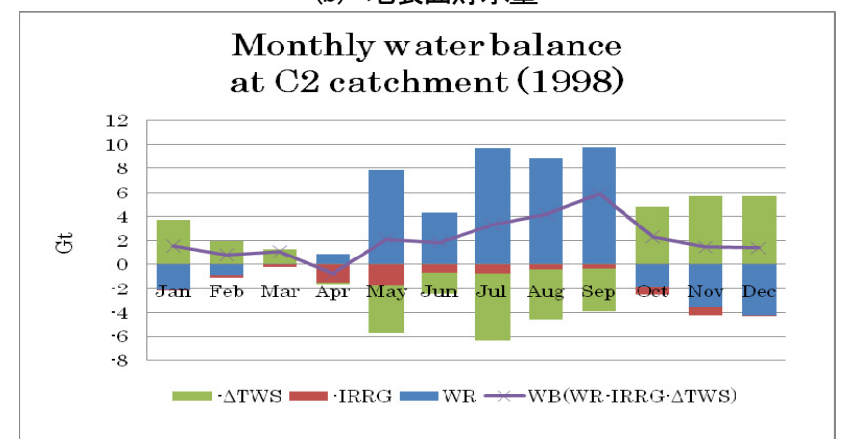

(d) 水収支

図-7＼cjkstart陸面過程解析結果(1998年，C2集水域) 
8 (a), (b) に示す. 青グラフ・緑グラフが解析された貯水 量変化, 日流入量を, 赤グラフ・紫グラフが 観測され た貯水量変化，日流入量を示している．モデルの解析値 は，貯水池一の流入量を精度よく再現している事が分か る. また，一年間を通して貯水容量を再現している事か ら, 陸面過程解析において, 貯水池上流域での水収支が 精度よく解析されている事が示唆される. 既に述べたよ うに, 乾季貯水容量は, その期の乾季作農地面積を定め る上で，重要な要素である。中長期の気象予測が得られ た場合に，長期的な貯水池操作計画を定める上で，貯水 容量を追跡可能な点は大きな効果を持つと期待される.

\section{（4）流出過程解析結果}

ここでは，C2地点乾季の河川流量結果を示寸．灌湛 を組み込んだ効果を議論するため, 灌泊を組み込んだ流 量解析と, 組み込まずに流量解析を行う2 ケースで解析 を行った．図-9に解析結果を示す，黒グラフが観測河川 流量, 赤グラフが灌溉を組み込んだ流量解析結果, 緑グ ラフが灌泊を組み込まずに行った流量解析結果, 青の七 ストグラムが集水域の平均時間降雨量である. 図-9より, 灌泊取水を考慮しなかった場合に, 解析流量が過大評価 である事が確認できる。しかしながら，灌溉を組み込ん だ解析結果より，陸面過程での灌沮取水の発生時期，発 生量の推定が不十分であったと確認できる. なお，河川 流量が定期的に振動するのは，境界条件に用いている貯 水池放流量は，土，日曜日にその放流量を減少させるた めである.

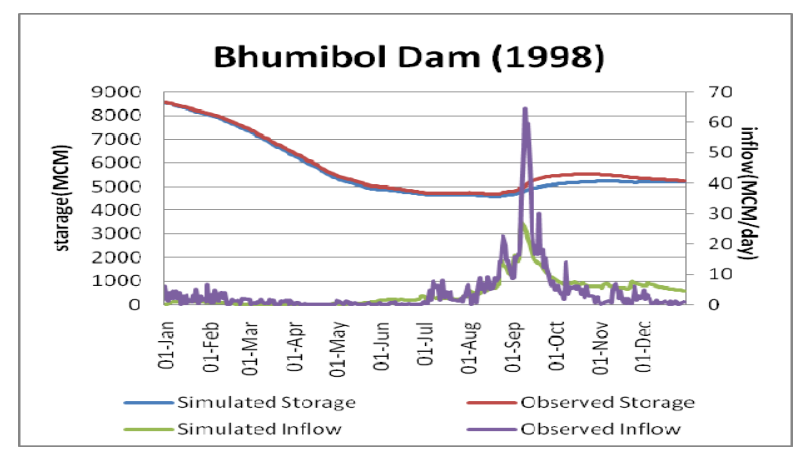

(a) Bhumibol Dam

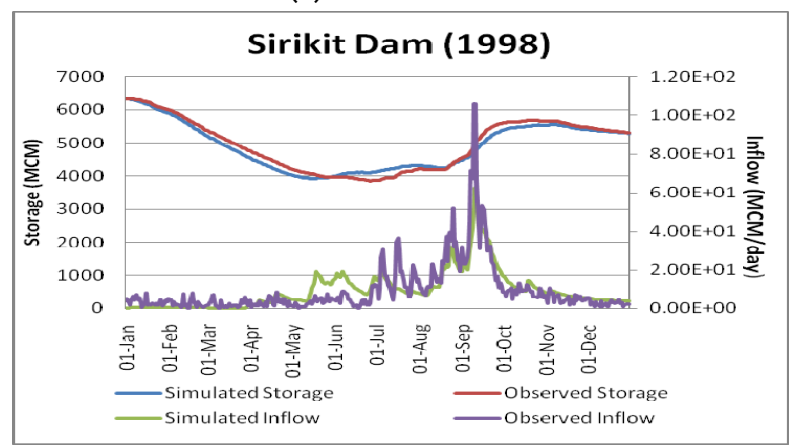

(b) Sirikit Dam

図-8＼cjkstart貯水池貯水量, 流入量年変化（1998年）

\section{（5）農事暦作成手法の改善}

流出過程解析で課題であった，灌激取水の発生時期， 発生量推定方法の改善を行った. 図-9より, 灌激取水の 発生が3-5月に集中し，1-2月の乾季河川流量は過大評価 である. 現状の農事暦作成手法では，乾季初期での耕作 が農事暦を反映されていない可能性が示唆される.

農事暦の作成に用いる各グリッドの $n N D V I は ， 今$ 回の ケースでは水田の判定された $1 \mathrm{~km} メ ッ シ ュ n N D V I$ 值を抽 出し, その平均值を用いている. しかし, 公開されてい るグローバル土地利用プロダクトには精度の限界がある。 例えば土地被覆データは, 最も基本的かつ重要なデータ であり, 複数の機関から $1 \mathrm{~km}$ 全球土地被覆データが提供 されているが, 最近の比較研究では, ピクセル毎の土地 被覆の一致度は $60 \%$ 程度とされている ${ }^{17}$. そこで, 現在 当研究室で開発が進められている, 全球 $1 \mathrm{~km}$ 作物分類図 18)を用いて水田の抽出を行った. 全球 $1 \mathrm{~km}$ 作物分類図は, 萬らの手法 ${ }^{8}$ を用いて解像度 $1 \mathrm{~km}$ で5作物（稲，小麦， 大豆，コーン，冬小麦）に分類されたプロダクトで ある.このプロダクトにおいて稲と判定されたピク セルから，水田のフェノロジーの抽出を行った。 ま た, 京都大学東南アジア研究所から提供されている,

AgroSEAD(http://sead.cseas.kyoto-u.ac.jp/index.htm) を用い て土地利用データを作成した. Agro-SEADは県単位での 作物の作付面積を整備しており, FAOと比較して高精度 の土地利用分布データの作成が可能である。これらの手 法を適用し, 灌泊取水量を陸面過程で推定し, 流出過程 に組み込み得られた解析結果を図-10に示寸，図-10より 河川流量の再現性が大きく向上していることが確認され

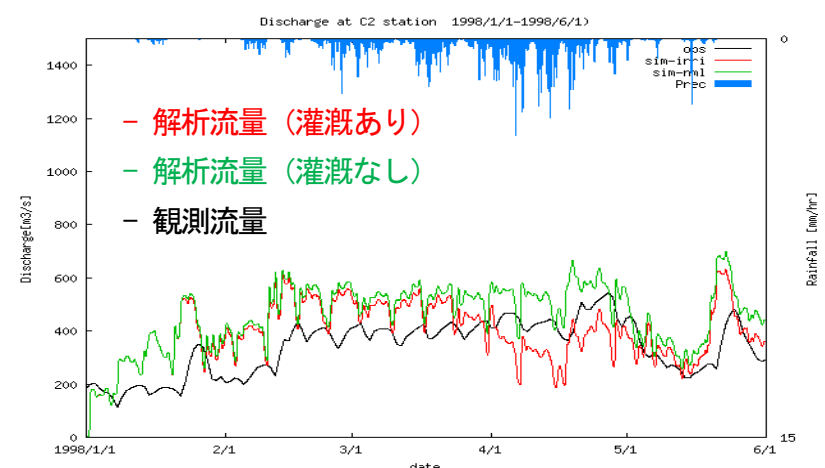

図-9 農事暦改善前C2地点時間河川流量（1998年, 乾季）

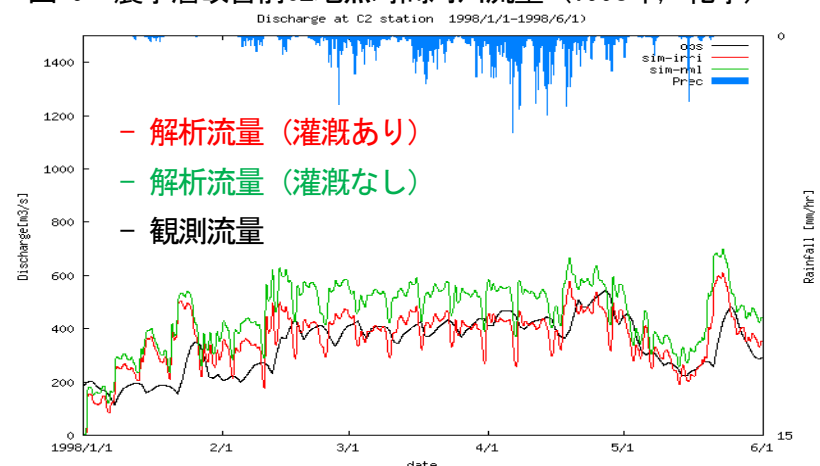

図-10 農事暦改善後C2地点時間河川流量（1998年, 乾季） 
る. 新たな農事暦作成手法が, 乾季灌泊必要水量とその 発生時期の推定精度改善に大きく寄与したといえる. 農 事暦の作成手法の改善による最も大きな点は, 二期作の フェノロジーが抽出可能になった点である。これにより， 従来の手法で問題であった「乾季初期において, 実際に は耕作が行われているが，農期と判定されない」グリッ ドをなくすことが可能となった，なお，1-2月には，河 川流量の再現性に大きな改善が見られない。この問題は, 農事暦作成時における，農期開始時期の特定手法に原因 があるが，水面の存在が抽出可能なリモートセンシング データNDWIの活用により解決可能である. 今後, NDWIにより稲作の開始時期に水田に水を張る時期をと らえる, 新たな農期開始時期の特定手法を確立する必要 がある.

\section{5. 結論}

本研究では，灌激取水の影響を考慮した陸域水循環モ デルの構築を行った. 灌溍取・排水を流出・河川流下過 程に組み込んだ結果, 灌潛の影響を考慮した河川流量を 解析する事が可能になった. 構築されたモデルを, タイ のチャオプラヤ川流域に適用した結果, 中流域上流部の 水収支が精度良く再現され，貯水池貯水量の再現も可能 であった．また，灌溉の効果を組み込んだ結果，中流域 における乾季の河川流量の再現性が大きく向上寸る事が 確認された. 本研究で構築されたモデルは, グローバル なデータセットから構築を行っており, 流域独自のデー タとしての大規模貯水池情報と降水量のデータが得られ ると，他流域への適用も可能なモデルである. 今後は他 流域でのモデルの検証を行っていく予定である.

\section{参考文献}

1) Oki, T. and Kanae, S.: Global hydrological cycles and world water resources. Science, 313, pp1068-1072, 2006.

2) H. G. Savenije, P. Van der Zaag : Integrated water resources management: Concepts and issues, Physics and Chemistry of the Earth, Vol. 33, In Press, Corrected Proof, pp290-297,2008.

3) Shiklomanov,I.A : Appraisal and assessment of world water resources, Water international, Vol.25, No.6, pp.11-32,2000.

4) Shiklomanov,I.A : State Hydrological Institute (SHI) and United National Educational, Scientific and Cultural Organization UNESCO, Paris, 1999.

5) N.de Noblet-Ducoudre, S. Gervois: Coupling the soil-vegetation -atmosphere-transfer scheme ORCHIDEE to the agronomy model STICS to study the influence of croplands on the European carbon and water budgets, Agronomie,Vol.24,pp397-407,2004.

6) N. Hanasaki, S. Kanae, T. Oki.: An integrated model for the assessment of global water resources, Hydrol. Earth Syst. Sci., 12, pp 1007-1025, 1027-37, 2008.

7) 谷口智之, 増本隆夫ら: 多様な水田水利用を考慮した分布 型水循環モデルの開発( I ), (II),(III), 水文・水資源学会 誌,22(2),pp101-140,2009.

8) 萬和明, 田中賢治, 池淵周一: NDVI 時系列解析による全 球作物分類図の作成, 水工学論文集, 第 49 巻, pp379384,2005 .

9) Yorozu,K., K.Tanaka, and S.Ikebuchi : Creating a global 1degree dataset of crop type and cropping calendar through the time series analysis of NDVI for GSWP2 simulation considering irrigation effect, Proc. of 85th AMS Annual Meeting, 19th conference of Hydrology, 6.8, 2005.

10) 萬和明, 田中賢治, 池淵周一: 全球灌泊要求水量と降水量 の相関分析, 水工学論文集, 第 50 巻, pp535-540,2005.

11) Kenji Tanaka: Development of the new land surface scheme SiBUC commonly applicable to basin water management and numerical weather prediction model, doctoral dissertation, Kyoto University, 2004.

12) Viovy N., Arino O., Belward A. S.: The Best Index Slope Extraction (BISE): A method for reducting noise in NDVI timeseries. Int. J. Remote Sens., 13(8), pp1585-1590, 1992.

13) Sellers, P.J., Y.Mintz, Y.C.Sud, and A.Dalcher:A simple biosphere model ( $\mathrm{SiB})$ for use within general circulation models, Journal of the Atmospheric Sciences, Vol.43, No.6, pp.505-531, 1986.

14）小尻利治, 東海明宏, 木内陽. シュミレーションモデル での流域環境評価手順の開発，京都大学防災研究所年報, 第41 号B-2, pp119-134,1998.

15) Hirabayashi Y, Kanae S, Motoya K, Masuda K, Doll P.: A 59year (1948-2006) global near-surface meteorological data set for land surface models, Hydrological Research Letters 2: pp36-40, pp65-69, 2008.

16) Razzaque.A., Rainer L., M.M.Islam,: Water use Efficiency of Thabua irrigation project, Thaniland, Journal of Civil Engineering, Vol.CE28, No.2, 2000.

17) Herold, M., Woodcock, C., Mayaux, P., Baccini, A. and C. Schmullius: Some challenges in global land cover mapping: an assessment of agreement and accuracy in existing $1 \mathrm{~km}$ datasets, Remote Sensing of Environment, 112, pp2538-2556, 2008.

18）北宅洋，田中賢治ら：NDVI 及び分光反射率の時系列解 析による全球 $1 \mathrm{~km}$ メッシュ作物分類図の作成, 水文・水 資源学会 2010 年度研究発表要旨集, pp74-75,2010.

(2010. 9. 30受付) 